\title{
A note of thanks
}

This study is based on a lightly revised version of my PhD thesis, Neben dem Text: Kommentierung, Dekoration, Kritzelei - Der SeMaK (Das kleine Buch der Gebote) als Zeugnis der visuellen Schreiberkultur in Ashkenaz, which the Faculty of Humanities and Social Sciences at The University of Lucerne accepted after its submission in 2016. It was Professor Katrin Kogman-Appel who gave me the idea of publishing the German thesis in English. I am very grateful to her for doing so and for making so many valuable suggestions about this work as well. My sincere thanks to Carl Carter from Amper Translation Service for translating my thesis into English with such care and enthusiasm. I would also like to express my gratitude to Professor Günter Stemberger and Professor Charlotte Fonrobert for their critical appraisals of the study and for including it in the Studia Judaica series.

Many thanks to Dr Sophie Wagenhofer and Dr Eva Frantz at De Gruyter for the help they both provided in finding solutions to issues I encountered during the process of publishing this book.

And last but not least, I would like to thank my family and my friends Sheila Briand, Andrea Gemma Sommaruga, Susanne Hess, Anita Moré and Christian Widmer - you have all been a wonderful help and support to me. 
